\title{
Komparasi Metode Multilayer Perceptron (MLP) dan Long Short Term Memory (LSTM) dalam Peramalan Harga Beras
}

\author{
Steven Sen ${ }^{1}$, Dedy Sugiarto ${ }^{2}$, Abdul Rochman ${ }^{3}$ \\ ${ }^{1,3}$ Program Studi Teknik Informatika, Fakultas Teknologi Industri, Universitas Trisakti, Jakarta, Indonesia \\ stev.strife@gmail.com \\ ${ }^{2}$ Program Studi Sistem Informasi, Fakultas Teknologi Industri, Universitas Trisakti, Jakarta, Indonesia
}

Diterima 21 April 2020

Disetujui 17 Juni 2020

\begin{abstract}
Rice is one of the main commodities in Indonesian society. The main problem with rice nationally is inflation of rice prices. Therefore, this research predicts the price of rice using Multilayer Perceptron (MLP) artificial neural network architecture and deep learning: Long Short Term Memory (LSTM) to anticipate these problems. The data used in this study are real data on rice prices during 2016 - 2019 obtained from PT. Food Station. The total dataset is 1307 with the distribution of 1123 as data train and 184 as test data. The final results obtained in this study are LSTM superior to MLP, with the value of Root Mean Square Error (RMSE) training data: 0.49 RMSE loss value of test data is 0.27. The most optimal LSTM model from 3 tests conducted, is a model with a number of hidden layers $=16$ and epochs $=150$ times.
\end{abstract}

Index Terms-Artificial Neural Network, Deep Learning, Forecasting Time Series, Long Short Term Memory (LSTM), Multilayer Perceptron (MLP)

\section{PENDAhUluan}

Beras merupakan komoditi pokok bagi masyarakat Indonesia sampai saat ini. Prediksi terhadap harga beras sangat diperlukan untuk mewujudkan stabilisasi harga bahan pokok guna tercapainya ketahanan pangan nasional, terutama pada masa pandemi Covid19 seperti sekarang. Tentunya pada masa sulit ini, diharapkan harga-harga pangan tetap stabil untuk menunjang kehidupan masyarakat, terutama beras. Data harga beras yang dihimpun pemerintah tiap tahunnya, termasuk dalam tipe data time series.

Banyak metode machine learning tersedia untuk memprediksi data time series, baik yang memiliki arsitektur shallow seperti : Principal Component Analysis (PCA), Isomap, dan Support Vector Machine (SVM), maupun arsitektur deep seperti: Convolutional Neural Network (CNN), Multilayer Perceptron (MLP), dan Long Short Term Memory (LSTM).

Multilayer Perceptrons (MLP) adalah arsitektur perceptron yang paling banyak digunakan untuk jaringan saraf. Lapisan perceptron digabungkan dan membentuk arsitektur multilayer, hal ini memberikan kompleksitas yang diperlukan dari pemrosesan jaringan saraf. Dengan menambahkan lebih banyak lapisan dan lebih banyak neuron per lapisan, akan meningkatkan spesialisasi model untuk melatih data [1].

LSTM merupakan sebuah arsitektur RNN [2] yang memiliki memory cell. Dengan memory cell, arsitektur LSTM dapat bekerja lebih baik dibanding jaringan saraf rekuren biasa, karena memiliki kemampuan untuk mengingat informasi untuk periode waktu yang lebih lama, sehingga menjadikannya algoritma yang lebih baik untuk prediksi data berjenis time series [3].

Penelitian ini bertujuan untuk melakukan prediksi dan komparasi model terhadap data time series harga beras jenis IR-64 kualitas III selama 24 bulan pada tingkat grosir yang didapatkan dari website PT.Food Station. Metode yang akan digunakan adalah komparasi antara jaringan saraf tiruan yaitu Multilayer Perceptron (MLP) dan deep learning dengan arsitektur Long Short Term Memory (LSTM) yang akan dibangun dengan environment berbasis bahasa python. Hal ini termasuk sebagai inovasi baru dalam perbandingan kedua model jaringan syaraf tiruan dalam bidang deep learning peramalan data time series terhadap permasalahan yang dibahas, mengingat semakin besarnya data dan kompleksnya kebutuhan akan pengolahan data.

Proses dalam penelitian ini adalah mencari nilai prediksi dengan akurasi terbaik antara model MLP dan LSTM, serta membuat plot perbandingan data test dengan data hasil prediksi. Tingkat keakuratan dari tiap model, akan diukur menggunakan algoritma Root Mean Squared Error (RMSE) sesuai skenario yang penulis buat.

\section{TINJAUAN PUSTAKA}

\section{A. Multilayer Perceptron (MLP)}

Multilayer merupakan bentuk lapisan perceptron yang digabungkan, dengan menambahkan lebih banyak layer dan neuron tiap layer. Multilayer 
Perceptron (MLP) sendiri merupakan arsitektur yang paling banyak digunakan untuk jaringan saraf.

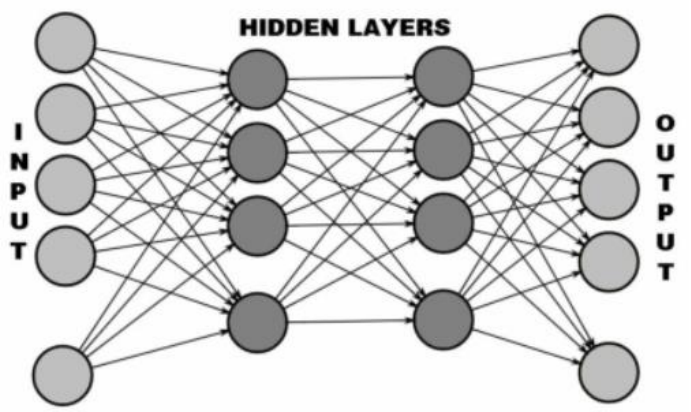

Gambar 1. Deep neural network MLP [1]

Pemrosesan dari layer input ke hidden layer dan kemudian ke lapisan output adalah disebut forward propagation. Jumlah (input $*$ bobot) + bias diterapkan pada setiap layer dan kemudian nilai fungsi aktivasi disebarkan ke layer berikutnya. Lapisan selanjutnya bisa berupa hidden layer lain atau output layer [1].

MLP dilatih dari data pelatihan melalui proses yang disebut backpropagation. Proses ini dapat digambarkan sebagai cara untuk memperbaiki kesalahan secara progresif segera setelah terdeteksi.

Pada awalnya, semua bobot ditetapkan secara acak. Kemudian jaringan diaktifkan untuk setiap input dalam set pelatihan: nilai disebarkan ke depan (forward propagation) dari tahap input melalui tahap tersembunyi ke tahap output di mana prediksi dibuat.

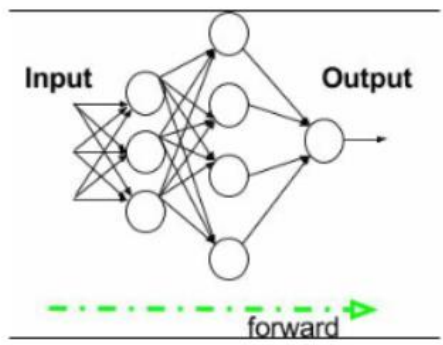

Gambar 2. Feed forward

Karena nilai real yang diamati dalam set pelatihan diketahui, maka memungkinkan untuk menghitung kesalahan yang dibuat dalam prediksi. Proses kerja utama dalam backtracking adalah melakukan alur kembali dari output menuju input dengan menggunakan algoritma pengoptimal yang tepat, seperti gradient descent, untuk menyesuaikan bobot (weight) jaringan saraf dengan tujuan mengurangi kesalahan.

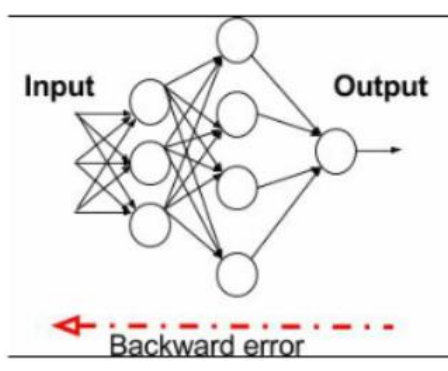

Gambar 3. Backpropagation

Proses feed propagation dari input ke output dan backpropagation diulang beberapa kali sampai kesalahan mencapai nilai di bawah ambang batas yang telah ditentukan [4].

\section{B. Recurrent Neural Network (RNN)}

Recurrent Neural Network (RNN) adalah jenis arsitektur Neural Network (jaringan saraf tiruan) dimana output dari hidden layer akan menjadi input bagi pemrosesan berikutnya. Ciri RNN adalah melakukan prediksi terhadap data tidak hanya menggunakan input pada satu waktu saja, akan tetapi juga membutuhkan masukan dari input sebelumnya, sehingga antar input saling berhubungan dan menggunakan hubungan tersebut untuk memberikan informasi ke seluruh hidden layer yang ada dalam RNN. RNN memiliki memori yang berisikan hasil rekaman informasi yang dihasilkan sebelumnya. Persamaan yang terbentuk adalah forward propagation dalam RNN (1), hidden layer (2), output gate (3), dan target (4).

$$
\begin{gathered}
a^{(t)}=b+W h^{(t-1)}+U x^{(t)} \\
h^{(t)}=\tanh \left(a^{(t)}\right) \\
o^{(t)}=c+V h^{(t)} \\
\hat{y}^{(t)}=\operatorname{softmax}\left(o^{(t)}\right)
\end{gathered}
$$

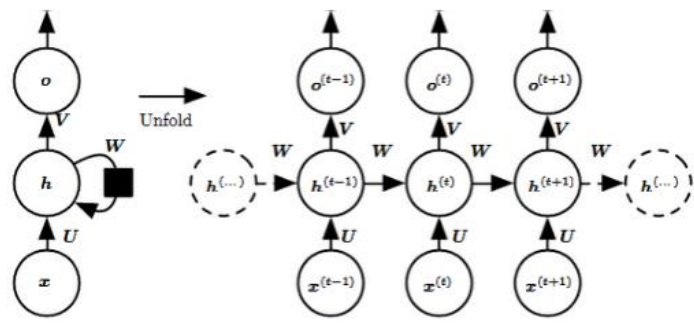

Gambar 4. Recurrent Neural Network dan formulasinya [5]

Satu masalah pada arsitektur RNN adalah masalah menghilangnya gradien (vanishing problem) pada proses backward pass [4]. Cara yang cukup populer 
untuk mengatasi vanishing problem adalah dengan menggunakan unit RNN yaitu Long Short Term Memory (LSTM) [6].

\section{Long Short Term Memory (LSTM)}

LSTM adalah jenis RNN khusus yang bekerja lebih baik dalam praktiknya, dikarenakan adanya pembaruan dari persamaan dan adanya dinamika backpropagation didalamnya [7]. Arsitektur Long Short Term Memory network (LSTM), seperti terlihat pada gambar 3, memiliki gate yang berfungsi untuk menghapus maupun menambah informasi yaitu forget gate, output gate, dan input gate. [8].

Persamaan yang terbentuk dari forget gate (1), input gate (2), output gate (3), lapisan tanh menciptakan vektor nilai kandidat baru (4), cell state (5), dan hidden layer (6) adalah:

$$
\begin{gathered}
f_{t}=\sigma\left(W_{f} \cdot\left[h_{t-1}, x_{t}\right]+b_{f}\right) \\
i_{t}=\sigma\left(W_{i} \cdot\left[h_{t-1}, x_{t}\right]+b_{i}\right) \\
o_{t}=\sigma\left(W_{o}\left[h_{t-1}, x_{t}\right]+b_{o}\right) \\
\tilde{C}_{t}=\tanh \left(W_{C} \cdot\left[h_{t-1}, x_{t}\right]+b_{C}\right) \\
C_{t}=f_{t} * C_{t-1}+i_{t} * \tilde{C}_{t} \\
h_{t}=o_{t} * \tanh \left(C_{t}\right)
\end{gathered}
$$

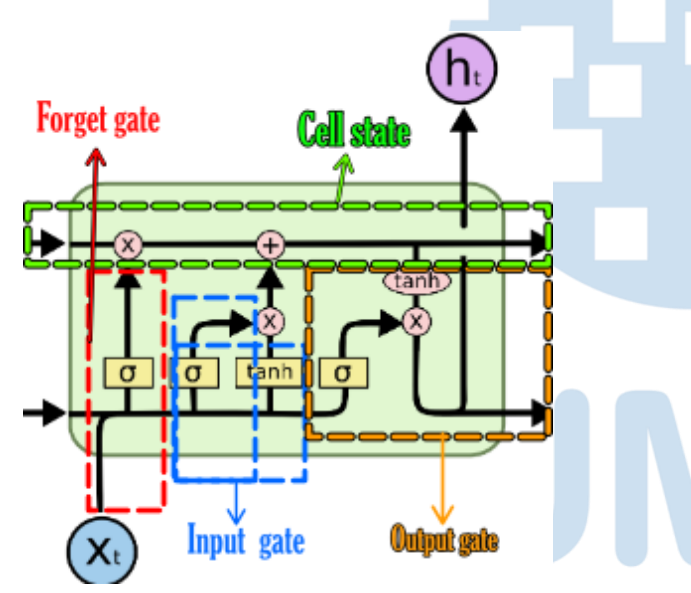

Gambar 5. Unit dari LSTM [6]

- Forget Gate: secara kondisional memutuskan apakah suatu informasi harus dibuang atau tidak dari pemrosesan.

- Input Gate: secara kondisional untuk menentukan sebuah masukan akan ditambahkan ke dalam memori cell state saat itu atau tidak [9].

- Cell state ini berfungsi sebagai memori atau ingatan untuk sebuah layer. Nilai suatu cell state dimanipulasi menggunakan sebuah sistem gerbang.

- Output Gate: secara kondisional memutuskan apa yang akan dihasilkan berdasarkan input dan memori blok [6].

\section{Deep Learning with Keras}

Keras adalah framework deep learning untuk Python yang menyediakan cara mudah untuk mendefinisikan dan melatih hampir semua jenis model deep-learning. Keras awalnya dikembangkan untuk para peneliti, dengan tujuan memungkinkan eksperimen berjalan lebih cepat. Sekarang, Keras adalah framework terpopuler di Kaggle dan berbagai kompetisi deep learning dunia [10]. Framework ini mendukung 2 bahasa data science yang paling populer yaitu: R and Python [11]. Kelebihan yang ditawarkan adalah dengan munculnya fitur-fitur : membuat code berjalan mulus pada CPU atau GPU, user-friendly API yang membuatnya mudah untuk membuat prototipe sebuah deep-learning, dan mendukung model RNN [10].

\section{Metode Penelitian}

Dalam membangun model LSTM ini, membutuhkan beberapa tahapan proses. Proses-proses tersebut terdiri dari proses preprocessing data, inisialisasi parameter, training jaringan LSTM, dan melakukan uji terhadap data testing. Dalam pembangunan sistem, dataset yang didapatkan diolah terlebih dahulu dengan menggunakan teknik normalisasi min max scaling. Dilakukan inisialisasi pada setiap parameter, setelah itu dilakukan training pada arsitektur jaringan saraf yang dibuat sesuai dengan parameter yang telah ditetapkan. Selanjutnya dilakukan uji pada model LSTM, hasil dari proses training terhadap data testing. Proses tersebut terus diulang hingga mendapatkan model dengan akurasi yang baik.

\section{A. Tahap Preprocessing Data}

Dataset yang digunakan adalah data real harga beras dari tanggal 1 Januari 2016 s.d 31 Januari 2020. Untuk meminimalkan error, dilakukan normalisasi pada dataset dengan mengubah data aktual menjadi nilai dengan range interval $[0,1]$. Teknik normalisasi yang digunakan adalah dengan min-max scaling.

Dataset kemudian dibagi dalam data train dan tes. Data train adalah data dari tanggal 1 Januari 2016 sampai 31 Juli 2019. Sedangkan data tes adalah sisanya, yaitu data dari tanggal 1 Agustus 2019 s.d 31 Januari 2020.

Tabel 1. Pembagian data

\begin{tabular}{|c|c|}
\hline Data Latih & Data Tes \\
\hline 1245 Data & 184 Data \\
\hline $01-01-2016$ & $01-08-2019$ \\
s.d & s.d \\
$31-07-2019$ & $31-01-2020$ \\
\hline \multicolumn{2}{|c|}{ Total data : 1429 } \\
\hline
\end{tabular}

Data train dan tes di-reshape menjadi 3 dimensi. 


\section{B. Inisialisasi Parameter}

\section{B.1 Model MLP}

Setelah dataset dilakukan preprocessing, dan selanjutnya menentukan inisialisasi parameter dasar. Pada MLP yang dibutuhkan antara lain:

Tabel 2. Parameter model MLP

\begin{tabular}{|l|l|}
\hline \multicolumn{1}{|c|}{ Paramater } & \multicolumn{1}{c|}{ Jumlah } \\
\hline Total layer & 5 \\
\hline Input layer & 1 layer $(64$ neuron) \\
\hline Hidden layer & 3 layer (128,128,8 neuron) \\
\hline Output layer & 1 neuron \\
\hline Jumlah epochs & 100 \\
\hline
\end{tabular}

\section{B.2 Model LSTM}

Inisialisasi parameter pada LSTM yang akan dibangun yaitu:

Tabel 3. Parameter model LSTM

\begin{tabular}{|l|l|}
\hline \multicolumn{1}{|c|}{ Paramater } & \multicolumn{1}{|c|}{ Jumlah } \\
\hline Total layer & 4 \\
\hline Hidden layer & 1 layer, 64 neuron \\
\hline $\begin{array}{l}\text { Jumlah LSTM cell } \\
\text { (input layer) }\end{array}$ & 128 neuron \\
\hline Output layer & 1 neuron \\
\hline Jumlah epochs & 100 \\
\hline
\end{tabular}

\section{Tahap Analisis dan Perancangan Model}

C.1 Model MLP

Tahap analisis dan perancangan model dilakukan setelah data melewati tahapan preproccesing. Model yang digunakan di penelitian ini, yaitu MLP.

- Digunakan dataset train untuk melatih model MLP. Pada tahap awal, model dibangun dengan memanggil fungsi sequential.

- Kemudian ditambahkan 1 buah layer input MLP dengan dense 64 neuron, input dimension $=1$, dan activation $=$ 'relu'.

- Ditambahkan 3 hidden layer dengan jumlah neuron masing-masing 128, 128, dan 8 .

- Pada layer terakhir, yaitu output layer dengan 1 buah neuron.

- Digunakan loss function yaitu RMSE dan optimizer Adam.

- Terakhir model dilatih dengan menggunakan fungsi fit, yang menggunakan parameter data train.

\section{C.2 Model LSTM}

Tahap analisis dan perancangan model dilakukan setelah data melewati tahapan preproccesing. Model yang digunakan kali ini yaitu LSTM dengan detail sebagai berikut:

- Digunakan dataset train untuk melatih model LSTM. Pada tahap awal, model dibangun dengan menggunakan fungsi sequential.

- Kemudian dibuat model dengan 1 buah layer LSTM sebagai input layer, dengan dimensi $(1,1), 1$ hidden layer dengan 64 neuron, dan output 1 neuron.

- Digunakan loss function yaitu RMSE dan optimizer Adam.

- Terakhir model dilatih dengan menggunakan fungsi fit, yang menggunakan parameter data train.

Tahap analisis dan perancangan model dilakukan setelah data melewati tahapan preproccesing. Model yang digunakan di penelitian ini, yaitu MLP.

\section{Testing}

Model yang telah dilatih pada proses training, akan diuji dengan menggunakan data test dari proses preprocessing data. Model akan menghasilkan nilai prediksi harga beras. Dilakukan juga proses perhitungan nilai RMSE pada hasil data train dan data test.

\section{D.1 Skenario Pengujian MLP}

Skenario pengujian dalam penelitian ini adalah menganalisa dampak tiap parameter terhadap akurasi yang didapatkan. Parameter yang diuji berupa jumlah neuron pada input layer dan besarnya epoch maksimum untuk menghasilkan bobot MLP yang optimal. Berikut adalah nilai parameter yang akan diuji:

- Jumlah neuron input : 64,128, 256

- Jumlah Epoch : :100, 150, 200

Dilakukan observasi sebanyak 3 kali. Hal ini dilakukan karena tidak cukup dilakukan observasi hanya sekali saja, karena hasil yang didapatkan bisa saja kebetulan baik ataupun buruk.

\section{D.2 Skenario Pengujian LSTM}

Skenario pengujian dalam penelitian ini adalah menganalisa dampak tiap parameter terhadap akurasi yang didapatkan. Parameter yang diuji berupa jumlah neuron pada hidden layer dan besarnya epoch maksimum untuk menghasilkan bobot LSTM yang optimal. Berikut adalah nilai parameter yang akan diuji:

- Jumlah neuron hidden : 64,128, 256

- Jumlah Epoch : : 100, 150, 200 
Dilakukan observasi sebanyak 3 kali. Hal ini dilakukan karena tidak cukup dilakukan observasi hanya sekali saja, karena hasil yang didapatkan bisa saja kebetulan baik ataupun buruk.

\section{E. Membandingkan Data Hasil Prediksi dan Plotting Data}

Tahap akhir yaitu membandingkan data hasil prediksi model LSTM dengan data aktual dalam sebuah tabel. Nilai train dan prediksi juga divisualisasikan dalam bentuk grafik plot.

\section{HASIL DAN PEMBAHASAN}

Berdasarkan data real harga beras yang terdapat pada FoodStation, dapat dilihat bahwa terdapat kenaikan harga setiap awal tahun dibanding bulan lainnya terutama pada tahun 2018. Lonjakan tertinggi terdapat pada awal tahun 2018 yang mencapai harga lebih dari 12.500, diikuti lonjakan awal tahun 2019 yang juga cukup tinggi.

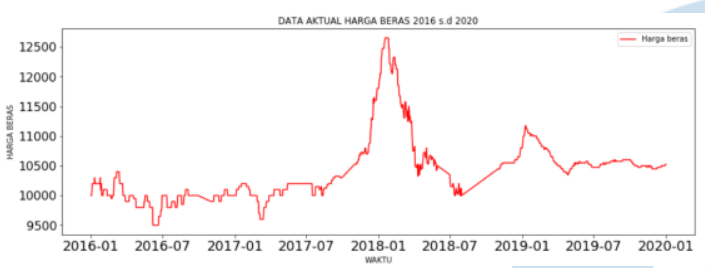

Gambar 6. Visualisasi data beras tanggal 1 Januari 2016 s.d 31 Januari 2020

Sedangkan harga beras cenderung menurun pada pertengahan tahun. Harga beras pada pertengahan tahun 2019 sampai awal tahun 2020 cenderung stabil. Dapat ditarik informasi bahwa pada awal tahun dan akhir tahun harga beras cenderung meningkat.

\section{A. Model MLP}

Tabel 4. Kombinasi uji coba MLP

\begin{tabular}{|l|c|c|c|c|}
\hline $\begin{array}{c}\text { Uji } \\
\text { Coba } \\
\text { ke - }\end{array}$ & $\begin{array}{c}\text { Jumlah } \\
\text { neuron } \\
\text { hidden } \\
\text { layer }\end{array}$ & epochs & $\begin{array}{c}\text { Nilai RMSE } \\
\text { Train }\end{array}$ & $\begin{array}{c}\text { Nilai RMSE } \\
\text { Tes }\end{array}$ \\
\hline 1 & 64 & 100 & 52.52 & 21.14 \\
\hline 2 & 128 & 150 & 95.38 & 39.32 \\
\hline 3 & 256 & 200 & 88.98 & 50.86 \\
\hline
\end{tabular}

Berdasarkan lampiran Tabel 4, menunjukkan hasil bahwa model MLP dengan jumlah neuron input layer $=64$ dan epochs $=100$, menghasilkan nilai RMSE yang lebih kecil dibandingkan dengan percobaan lainnya. Bisa dikatakan bahwa percobaan pertama lebih optimal dibanding dengan kedua percobaan lainnya. Jumlah input layer mengolah data input dan menghubungkannya dengan neuron output. Tidak ada aturan pasti mengenai jumlah hidden neuron yang paling optimal dalam memprediksi data time series contohnya harga beras ini, maka dilakukanlah percobaan untuk mengetahui model paling optimal.

\section{B. Model LSTM}

Tabel 5. Kombinasi uji coba LSTM

\begin{tabular}{|l|c|c|c|c|}
\hline $\begin{array}{c}\text { Uji } \\
\text { Coba } \\
\text { ke - }\end{array}$ & $\begin{array}{c}\text { Jumlah } \\
\text { neuron } \\
\text { hidden } \\
\text { layer }\end{array}$ & epochs & $\begin{array}{c}\text { Nilai } \\
\text { RMSE } \\
\text { Train }\end{array}$ & $\begin{array}{c}\text { Nilai RMSE } \\
\text { Tes }\end{array}$ \\
\hline 1 & 64 & 100 & 0.52 & 0,35 \\
\hline 2 & 128 & 150 & 0.49 & 0.27 \\
\hline 3 & 256 & 200 & 0.59 & 0.37 \\
\hline
\end{tabular}

Berdasarkan lampiran Tabel 5, menunjukkan hasil bahwa model LSTM dengan jumlah neuron hidden layer $=128$ dan epochs $=150$, menghasilkan nilai RMSE yang lebih kecil dibandingkan dengan percobaan lainnya. Bisa dikatakan bahwa percobaan kedua lebih optimal dibanding dengan kedua percobaan lainnya. Hidden layer mengolah neuron input dan menghubungkannya dengan neuron output, sehingga jumlah hidden neuron akan menentukan nilai output yang dihasilkan oleh unit LSTM.

Tabel 6. Perbandingan data aktual dan prediksi MLP

\begin{tabular}{|c|c|c|c|}
\hline & Harga & $\begin{array}{c}\text { Nilai } \\
\text { Prediksi }\end{array}$ & $\begin{array}{c}\text { Nilai } \\
\text { akurasi } \\
\text { RMSE }\end{array}$ \\
\cline { 3 - 4 } & Aktual & MLP & MLP \\
\hline 01 Jan 2016 & 10000 & 9968,594 & 0,937 \\
\hline 02 Jan 2016 & 10000 & 9968,594 & 0,937 \\
\hline 03 Jan 2016 & 10000 & 9968,594 & 0,937 \\
\hline 04 Jan 2016 & 10100 & 10034,286 & 4,945 \\
\hline 05 Jan 2016 & 10200 & 10253,814 & 4,362 \\
\hline ====== & $=====$ & $=====$ & $=====$ \\
\hline 27 Jan 2020 & 11225 & 11194,379 & 0,914 \\
\hline 28 Jan 2020 & 11225 & 11194,379 & 0,914 \\
\hline 29 Jan 2020 & 11250 & 11212,434 & 1,121 \\
\hline 30 Jan 2020 & 11250 & 11212,434 & 1,121 \\
\hline 31 Jan 2020 & 11250 & 11212,434 & 1,121 \\
\hline
\end{tabular}

Dari tabel perbandingan data aktual dan prediksi MLP, menunjukkan bahwa MLP memprediksi nilai harga dengan rentang yang cukup besar terhadap harga aktual. Nilai error RMSE cukup besar menandakan bahwa model ini kurang efektif dalam mengolah data time series harga beras.

Hasil training model LSTM, maka akan dihasilkan nilai prediksi harga dan loss pada bulan selanjutnya yaitu sebagai berikut: 
Tabel 7. Perbandingan data aktual dan prediksi LSTM

\begin{tabular}{|c|c|c|c|}
\hline \multirow{2}{*}{ Tanggal } & \multirow{2}{*}{$\begin{array}{c}\text { Harga } \\
\text { Aktual }\end{array}$} & $\begin{array}{c}\text { Nilai } \\
\text { Prediksi }\end{array}$ & $\begin{array}{c}\text { Nilai } \\
\text { akurasi } \\
\text { RMSE }\end{array}$ \\
\cline { 3 - 4 } & 10000 & LSTM & LSTM \\
\hline 01 Jan 2016 & 10000 & 9999.547 & 0,014 \\
\hline 02 Jan 2016 & 10000 & 9999.547 & 0,014 \\
\hline 03 Jan 2016 & 10100 & 10099.568 & 0,014 \\
\hline 04 Jan 2016 & 10200 & 10199.624 & 0,013 \\
\hline 05 Jan 2016 & $=====$ & $======$ & $======$ \\
\hline ====== & 11225 & 11227,099 & 0,063 \\
\hline 27 Jan 2020 & 11225 & 11227,099 & 0,063 \\
\hline 28 Jan 2020 & 11250 & 11252,168 & 0,065 \\
\hline 29 Jan 2020 & 11250 & 11252,168 & 0,065 \\
\hline 30 Jan 2020 & 11250 & 11252,168 & 0,065 \\
\hline 31 Jan 2020 & & & \\
\hline
\end{tabular}

Tabel perbandingan data aktual dan prediksi LSTM, menunjukkan bahwa LSTM berhasil memprediksi nilai harga dengan optimal dan mendekati harga aktual. Nilai error RMSE yang sangat kecil menandakan bahwa model ini cukup efektif dalam mengolah data time series harga beras. Terkait nilai MSE yang optimal, adalah tergantung dari data dan model yang dibangun.

Hasil plotting data train dan tes pada model MLP yang dibangun.

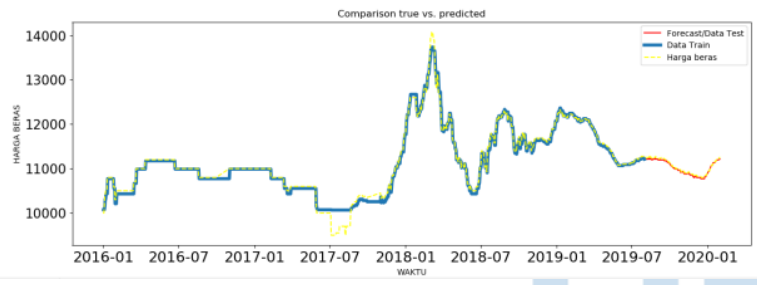

Gambar 7. Visualisasi data train dan tes MLP

Visualisasi data train (biru), tes (merah), dan data harga aktual (kuning) menunjukkan bahwa harga beras cenderung berubah secara signifikan terutama pada tahun 2018. Menurut training dan testing MLP, harga 6 bulan kedepan cenderung fluktuatif yaitu dari 1 Agustus 2019 s.d 31 Januari 2020 akan berkisar antara $10.600-11.100$. Garis harga prediksi dan aktual tidak nampak ada perbedaan, karena perbedaan nilai yang sangat kecil.

Hasil plotting data train dan tes pada model LSTM yang dibangun.

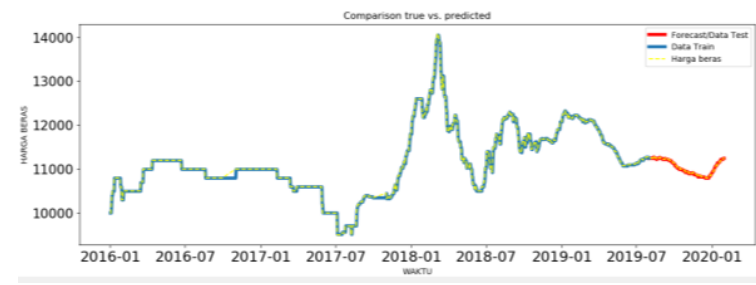

Gambar 8. Visualisasi data train dan tes LSTM

Visualisasi data train (biru), tes (merah), dan data harga aktual (kuning) menunjukkan bahwa harga beras cenderung tidak berubah secara signifikan seperti pada tahun 2018. Menurut prediksi LSTM, harga 6 bulan kedepan yaitu dari 1 Agustus 2019 s.d 31 Januari 2020 akan berkisar antara $10.300-10.700$. Garis harga prediksi dan aktual tidak nampak ada perbedaan, karena perbedaan nilai yang sangat kecil.

\section{SimPULAN}

Prediksi terhadap data time series harga beras pada PT. FoodStation dirancang dengan menggunakan perbandingan antara dua model Multilayer Perceptron (MLP) dan arsitektur Long Short Term Memory (LSTM). Sebagai data percobaan, digunakan data harga beras tanggal 1 Januari 2019 s.d 31 Juli 2019. Model MLP dan LSTM dibangun dengan library Keras dan menggunakan loss function yaitu RMSE.

Pada tahap forecasting, digunakan data 6 bulan terakhir harga beras sebagai data testing yang menghasilkan output prediksi harga dari kedua model. Perbandingan hasil output, menghasilkan kesimpulan bahwa model LSTM lebih akurat jika dilihat dari rentang dengan harga aktual dan nilai RMSE-nya yang lebih kecil dibandingkan MLP. Pada akhirnya, didapatkan nilai loss RMSE pada LSTM, yaitu training data score: $0.49 \mathrm{RMSE}$, test data score: 0.27 RMSE, dan hasil grafik plot yang menunjukkan bahwa tidak ada perbedaan signifikan antara hasil train dan testing dengan data aktual.

Penelitian ini, diharapkan dapat menjadi referensi pilihan metode untuk pengembangan penelitian lainnya dan dikembangkan lagi agar menghasilkan metode yang lebih akurat terutama dalam bidang forecasting deep learning.

\section{DAFTAR PUSTAKA}

[1] G. Ciaburro and B. Venkateswaran, Neural network with R, Packt Publishing, 2017.

[2] W. Ahmed and M. B. , "The Accuracy of the LSTM Model for Predicting the S\&P 500 index and the Difference Between Prediction and Backtesting," Degree Project in Technology, 2018.

[3] H. Prasetyanwar and J. , "Peramalan Nilai Tukar IDR-USD Menggunakan Long Short Term Memory," e-Proceeding of Engineering : Vol.5, No.2 Agustus 2018, vol. 5, p. 3820, 2018.

[4] A. GUlli and S. P. , Deep Learning with Keras, Birmingham: Packt Publishing Ltd, 2017. 
[5] J. Nabi, "Recurrent Neural Networks (RNNs)," [Online]. Available: https://towardsdatascience.com/recurrent-neuralnetworks-rnns-3f06d7653a85.

[6] C. Olah, "Understanding LSTM Networks," 27 August 2015. [Online]. Available: http://colah.github.io/posts/2015-08Understanding-LSTMs/.

[7] A. Karpathy, "The Unreasonable Effectiveness of Recurrent Neural Networks," 21 May 2015.
[8] J. Brownlee, "Time Series Prediction with LSTM Recurrent Neural Network in Python with Keras," 2016.

[9] L. Zaman, S. S. and M. H. , "Analisis Kinerja LSTM dan GRU sebagai Model Generatif," vol. 8, p. 143, 2019.

[10] F. Chollet, Deep Learning with Python, New York: Manning, 2018.

[11] F. Chollet and J. J. Allaire, Deep Learning with R, vol. 1, Manning Publications, 2017. 